\title{
Application of flow cytometry in marine phytoplankton research: current applications and future perspectives*
}

\author{
MARCEL J. W. VELDHUIS and GIJSBERT W. KRAAY \\ Netherlands Institute for Sea Research. P.O.Box 59, 1790 AB Den Burg, Texel, The Netherlands. \\ E-mail: Veldhuis@NIOZ.nl
}

\begin{abstract}
SUMMARY: A brief overview is given of current applications of flow cytometry (FCM) in marine phytoplankton research. This paper presents a selection of highlights and various technical and analytical problems we encountered during the past 10 years. In particular, the conversion of the relative values obtained in terms of size and fluorescence applying FCM to quantitative estimates of cell size, pigment concentration, genome size etc., is addressed. The introduction of DNA -cellcycle analysis made easily assessable by flow cytometry has been of great importance, allowing in situ measurement of species specific growth rates. Key questions in ecology such as factors determining the wax and wane of phytoplankton bloom can now be better answered in terms of species specific growth and mortality. Finally, flow cytometry provides detailed information of the physiological status of the individual algal cells. New staining methods enable us to distinguish between viable and non-viable cells and so will help us to elucidate the importance of "automortality" in aquatic ecosystems.
\end{abstract}

Key words: autofluorescence, automortality, DNA, flow cytometer, growth rate, phytoplankton, viability.

\section{HISTORY}

The first and so far best known application of flow cytometry (FCM) in aquatic sciences is in phytoplankton research originally aimed for ametric and ataxonomic purposes (Paau et al., 1978; Yentsch et al., 1983). Since the early 80 's FCM is generally accepted as an analysing technique (see also Burkill, 1987; Yentsch and Pomponi, 1986; Phinney and Cucci, 1989; Burkill and Mantoura, 1990; Olson et al., 1991). Despite the fact that the potentials are enormous it is still not a widely spread instrument, nor has its capacity been fully exploited.

\footnotetext{
*Received December 12, 1998. Accepted February 25, 2000
}

The configuration of most commercially available instruments is based on dealing with particles varying in size between 0.5 and $30 \mathrm{~mm}$ and particle numbers ranging from $10^{2}$ to $10^{6}$ per $\mathrm{ml}$, thus covering a major region of particle size distribution in the ocean (Fig. 1). Essentially the optical characteristics of single particles in a solution are measured during their passage through a narrow beam of light (lamp or laser). For this purpose the instrument is equipped with a set of scatter- and fluorescence detectors (mainly photomultipliers). Due to chlorophyll autofluorescence, allowing easy discrimination of the phytoplankton component, the technique has found its way into phytoplankton research, in particular that of picophytoplankton of the open oceans. 


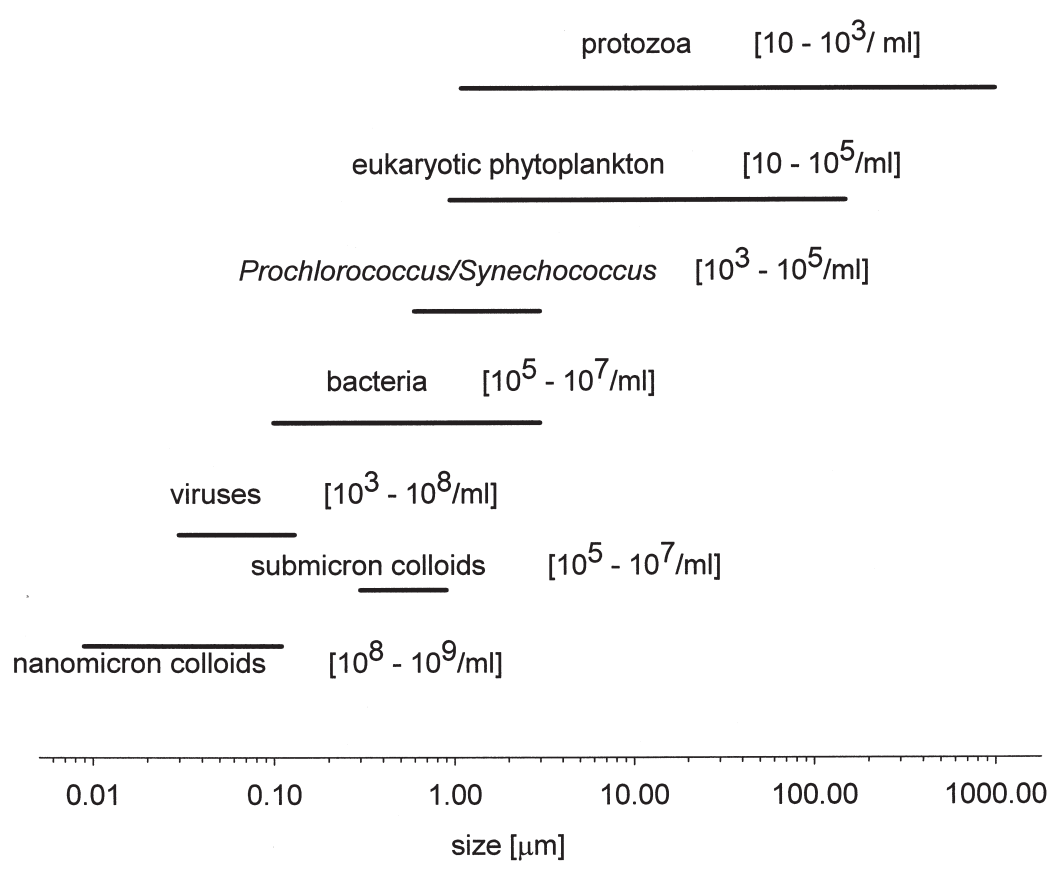

FIG. 1. - Abundances and size class distribution of living and non-living particles in the upper ocean (modified after Koike et al., 1990).

An inventory of unicellular phytoplankton shows that most species fall into the particle range the instrument can detect. However, the variability in size is far larger, ranging over 4 orders of magnitude $(0.7 \mu \mathrm{m}$ to $>1 \mathrm{~mm}$; Fig. 1). In addition, numerous species form chains (in particular diatoms) or produce colonies like Phaeocystis. This increases the size range another 10 to 100 fold. In contrast to the smaller species, with numbers exceeding $10^{8}$ per litre, the abundance of the larger phytoplankton species is much lower, often in the order of several hundred cells per litre.

All phytoplankton species contain chlorophyll- $a$ as well as DNA and concentrations per cell vary by a factor 50,000 and 20,000, respectively (Burkill and Mantoura, 1990; Holm-Hansen, 1969; Veldhuis et al., 1997a). It is obvious that a single instrument cannot accommodate this dynamic range. To facilitate a broader detection range ( $>4$ decades) and more detailed morphological features more sophisticated instruments have been designed like the Optical Plankton Analyzer (OPA), its successor EUROPA (Peeters et al., 1989; Dubelaar et al., 1989; Peperzak et al., 2000) and more recently its small scale version CytoBuoy (Dubelaar et al., 1999, Dubelaar and Gerritzen, 2000). An alternative instrument to count the larger and more complex particles is FlowCAM (Sieracki et al., 1998). This modified microscope has been designed to visualise digitised images of all particles passing the detector (see also Kachel and Wietzorrek, 2000).

\section{PHYTOPLANKTON (AUTO)FLUORESCENCE}

Phytoplankton species contain plant-pigments in a broad variety (Jeffrey et al., 1997), with chlorophyll $a$ as the major compound but single source of the red fluorescence signal (emission $>610 \mathrm{~nm}$ ). This chlorophyll fluorescence signal is the principle factor used to discriminate phytoplankton from other particles (Yentsch and Yentsch, 1979). Next, orange fluorescence (emission between 550 to 590 $\mathrm{nm}$ ) can be used to detect the second group of fluorescing photopigments (phycoerythrin). This photopigment is found only in a limited number of algal groups; typical in many coccoid Synechococcus spp. (Wood et al., 1985) and some Cryptophytes. The whole suite of accessory pigments in phytoplankton lack a distinct fluorescence signal. Only in multiple laser instruments additional information can be gained from these pigments (Olson et al., 1988; Hofstraat et al., 1991).

Like chlorophyll- $a$, which is commonly used as a proxy for phytoplankton biomass, the flow cytometric derived in vivo autofluorescence signal of the different clusters of phytoplankton can be used to estimate the biomass contribution of each algal group (Li et al., 1993; Shimada et al., 1993). In some cases the FCM-derived fluorescence signal co-varied in a linear manner with the chemically estimated chlorophyll $a$ biomass (Veldhuis et al., 1997b). On other occasions both the chlorophyll- $a$ concentration and 

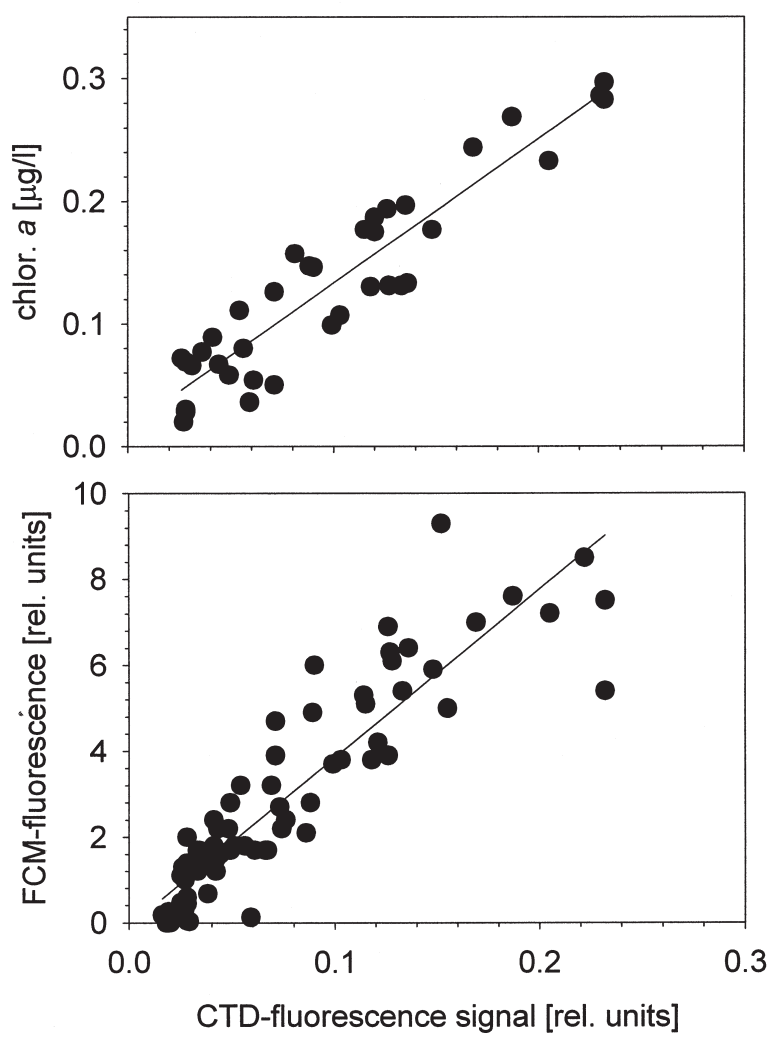

FIG. 2. - In vivo -fluorescence of CTD-attached fluorometer versus chlorophyll- $a$ concentration (upper panel, $\mathrm{n}=41, \mathrm{r}^{2}=0.813$ ) and versus FCM-autofluorescence (lower panel, $n=140, r^{2}=0.881$ ). Samples are taken at 5 locations in the (sub)tropical North Atlantic Ocean.

the FCM-fluorescence signals co-varied with the fluorescence measured with the fluorometer attached to the CTD (oligotrophic North Atlantic Ocean, Fig. 2).

Unfortunately, the chlorophyll fluorescence is also subject to large changes (over one order of magnitude). This is due to a variety of factors like: macro- and micro nutrients as well as the light climate (gradient) and history (diel changes). As a result there is no simple conversion of the chlorophyll based phytoplankton biomass to carbon units.

Alternatively, this rapid adaptation of the fluorescence could also be useful to examine environmentally induced variation in phytoplankton physiology (Sosik et al., 1989; Sakshaug et al., 1987; Veldhuis and Kraay, 1993).

Besides autofluorescence a variety of fluorochromes can be applied for fluorescent labelling cell specific components. Of all applied fluorochromes those labelling the cellular DNA are the most widely used ones in aquatic sciences. Current- ly a variety of DNA specific dyes are available which can be used to determine the genome size, base pair composition and ploidy (PI, Chrom A3, HOECHST \#33342, TOTO, PicoGreen, SYBGreen). The advantage of these dyes is that they are very selective in staining the genome (dsDNA or selective base-pairs) and the recently developed ones do not interfere with the chlorophyll autofluorescence. A detailed study of over 70 different strains of phytoplankton (comprising the major 12 Classes) showed a linear trend between cell size and DNA content (Veldhuis et al., 1997a). This trend was similar to the trend observed for the size and cellular chlorophyll fluorescence (Fig. 3). In both cases there was no Class-related clustering but some grouping was found at the lower range (Synechococcus and Prochlorococcus) and the higher range (Dinoflagellates) of the size-class spectrum.

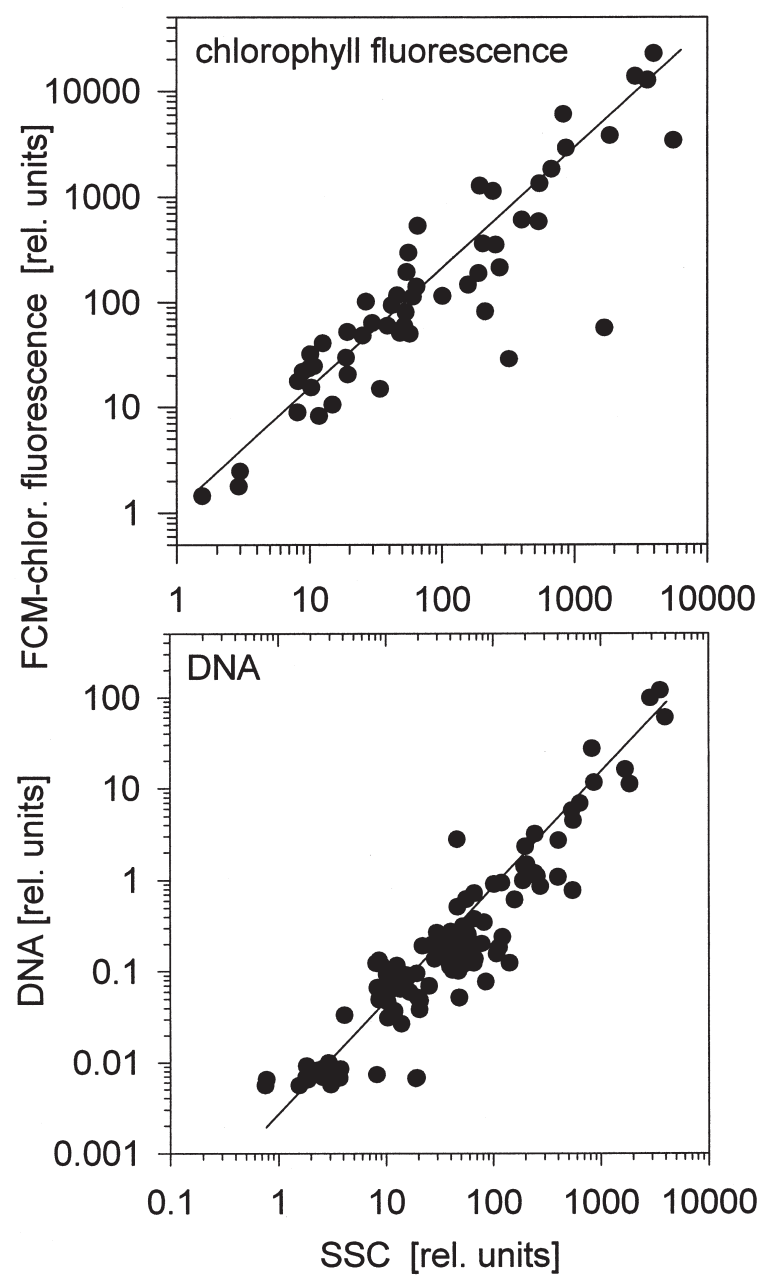

FIG. 3. - Phytoplankton chlorophyll FCM-autofluorescence ( $>650$ $\mathrm{nm}$ ) versus Side angle Scattered light of 70 strains of phytoplankton (upper panel) and versus DNA content (120 algal strains, lower panel) (modified after Veldhuis et al., 1997a). 


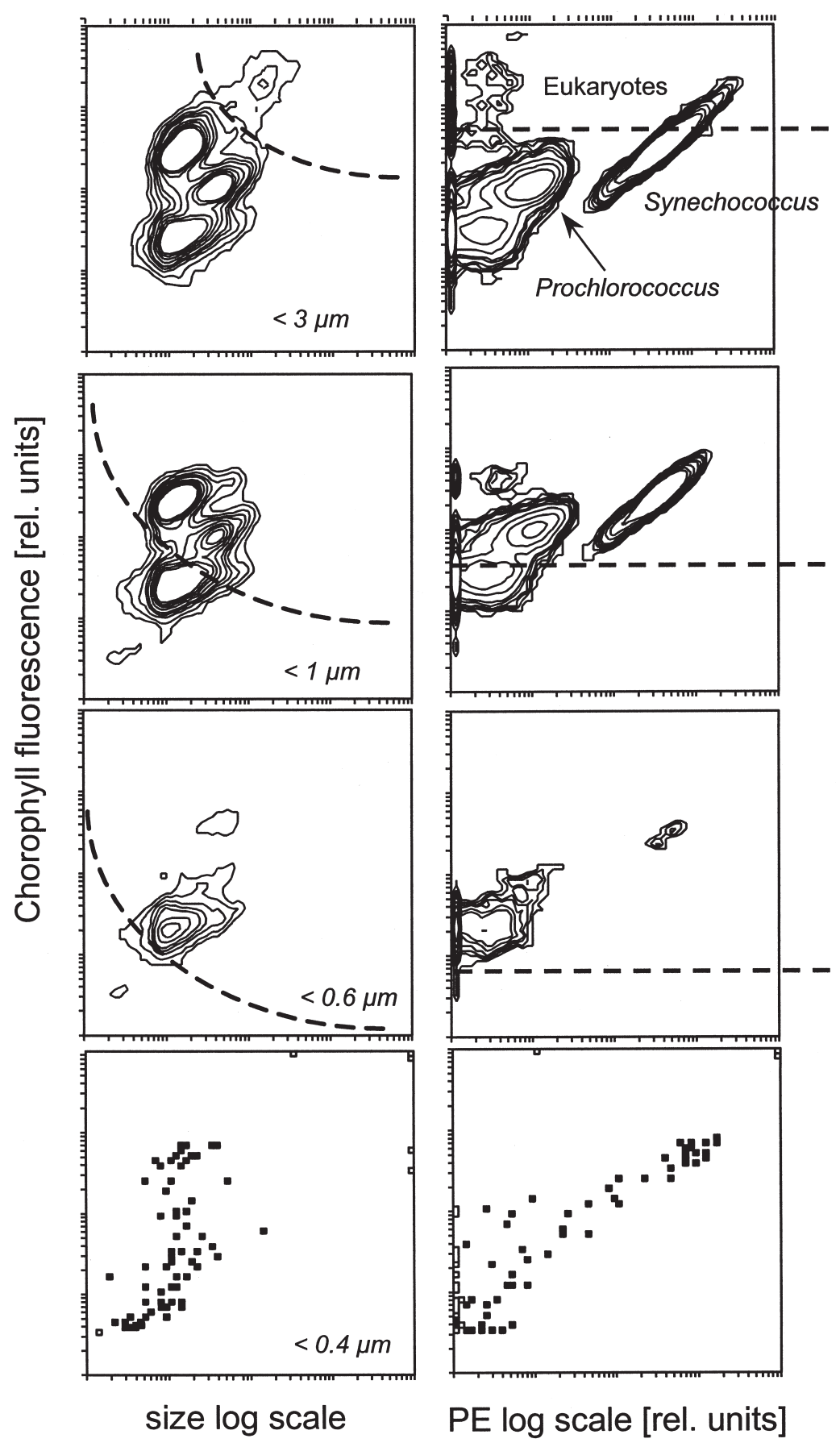

FIG. 4. - Bivariate cell density contour plots showing the side scatter versus chlorophyll and chlorophyll versus PE-fluorescence distribution of oceanic phytoplankton community prefiltered over 3,1, 0.6 and $0.4 \mu \mathrm{m}$ filters. Dashed lines indicate cut-off range of the filters (tropical North Atlantic ocean).

On a more detailed level, strain-related differences can be assessed as well (Vaulot et al., 1994; Medlin et al., 1996; Veldhuis et al., 1997a). In Phaeocystis and Emiliania huxleyi differences in genome size appear to match with differences found in the plant-pigment composition often matching geographical differences (Vaulot et al., 1994; Medlin et al., 1996).

\section{PHYTOPLANKTON SIZE AND BIOMASS}

With respect to the cellular scatter characteristics both Forward angle Scatter (FSC) and Side angle Scatter (SSC) of most phytoplankton species are not very discriminative. Therefore, the usefulness of these signals for taxon specific identification is limited. Only calcifying algae like Emiliania huxleyi, 
which are densely surrounded by coccoliths (minute plates of calcite) can be distinguished from the other plankton by their typical (high) scatter signature. Despite the fact that the resolution of the scatter signal is enhanced when using a polarising filter set in front of the SSC detector (Olson et al., 1989) this approach has not been widely applied.

For decades phytoplankton biomass has been estimated by converting cell size and shape into cell volume and calculating carbon using empirically derived relationships based on microscopic observations (Strathmann, 1967; Verity et al., 1992). In order to use the flow cytometric data the ametric values of the scatter signals have to be converted to more accurate estimates of cell size or volume. Spherical beads have been used, but these are only reliable in the particle size range above 5 $\mu \mathrm{m}$ (Chisholm, 1992). In general FSC is used as an estimate of cell size mainly because of the good correlation of this parameter with Coulter volume (Olson et al., 1989). For the smaller size range (picophytoplankton, $<3 \mu \mathrm{m}$ ) a different relationship between standard beads and cell sizes is found (Morel, 1991; Charpy and Blanchot, 1998). Alternatively, the plankton community can be size fractionated over filters, which differ in pore size for a rapid, but rather crude determination of the size distribution (Fig. 4).

For taxon specific estimation of the phytoplankton biomass those of Prochlorococcus and Synechococcus are usually calculated separately because these two species can easily be distinguished from the pico-eukaryotes (Li et al., 1993; Campbell et al., 1994; Li, 1995; Charpy and Blanchot, 1998).

More recently, we applied the genome size to calculate the carbon content of phytoplankton cells. As has been shown earlier (Holm-Hansen, 1969) and recently has been reconfirmed for an even larger size range, the genome size of phytoplankton varies proportionally with the carbon content of cells over 4 orders of magnitude (Veldhuis et al., 1997a). On average the dsDNA in unicellular phytoplankton remains fairly constant and accounts for $2 \%$ of the total carbon content. Only dinoflagellates tend to deviate from this relationship with a relatively larger genome size. A comparison of the carbon biomass estimates based on the scatter signals and the DNA-method for tropical phytoplankton (size range of 1 to 7 $\mu \mathrm{m})$ showed results which are in close agreement (Fig. 5).

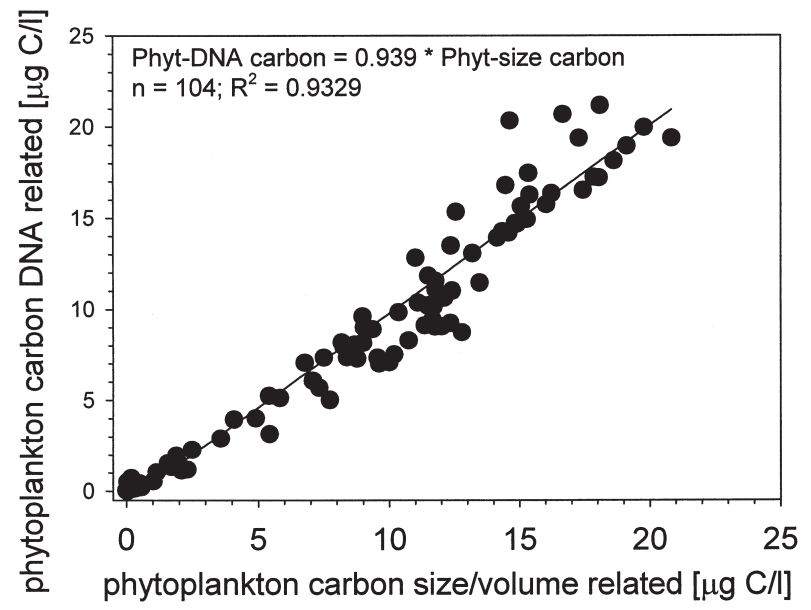

FIG. 5. - Phytoplankton carbon estimated based on size/volume distribution versus carbon based on DNA-carbon relationship as derived in Veldhuis et al., 1997a (samples taken in the tropical North Atlantic).

\section{COUNTING PHYTOPLANKTON CELLS}

Since commercial instruments are originally designed for qualitative purposes (semi-) quantitative measurements are still causing major problems. In some instruments this has been solved by counting a fixed volume, e.g. the Coulter XL-MCL is equipped with a $20 \mu 1$ loop or a module with a fixed counting time corresponding to 1,10 or $100 \mu \mathrm{l}$ analysing volume (Optoflow-MICROCYTE). Often beads are used as an internal standard but this is not recommended for several reasons. Firstly, most beads contain toxic substances (e.g. sodium azide or detergents) which can have a negative effect on living cells. Secondly, beads, in particular the smaller ones, stick easily to the tubing and sample vials. Weighting the sample vials prior to and after counting is still one of the best ways to estimate the particle number per unit of volume although not applicable on board a ship.

To check the counting efficiency during data acquisition a plot of the time versus cells number histogram during acquisition can be of help. Deviation from a straight line does indicate unwanted clogging or settling of the particles.

In general count rates should not exceed 200 to 400 particles per second when counting (sub)micron particles (Fig. 6). The actual cell numbers may be underestimated by as much as $70 \%$ at counting rates above 1500 per second and effect the intensity of the scatter and fluorescence signals as well. This unwanted side effect of counting particles has been observed in a variety of instruments (Coulter-XL, 

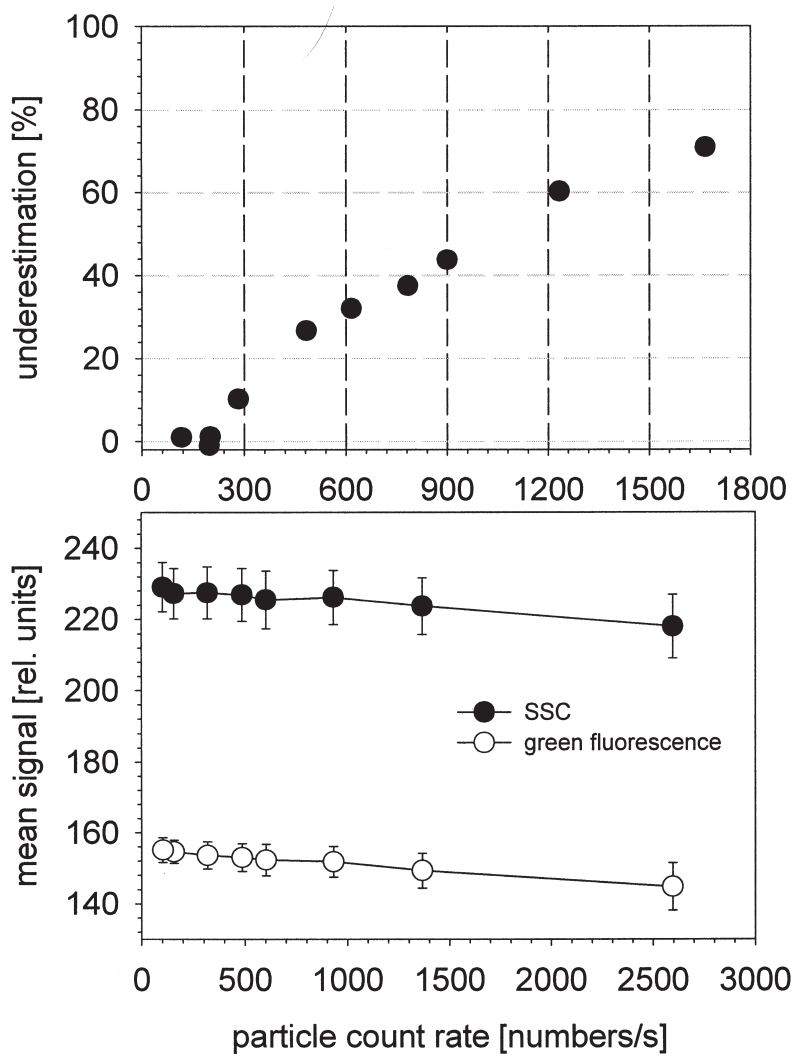

FIG. 6. - Effect of counting efficiency (expressed as \% underestimation in particle number) on the counting rate (Coulter XL-MCL, upper panel). Relative variation in scatter and fluorescence signals at different counting rates.

Elite and FACS-Scan). This observation contradicts the theoretical specifications of most modern instruments which are capable of handling much higher count rates, To reduce this effect a proper setting of the laser power, photomultiplier and discriminator/ threshold is crucial.

On the other hand, for proper statistics a sufficient number of cells needs to be analysed. A minimum is 1000 events per run, which implies a c.v. of $10 \%(\mathrm{Li}, 1990)$. This factor increases in importance in particular in the case of rare cell detection (Leary, 1994) and may come into conflict with the above mentioned count rate problem. Typical conditions at which these conflicting situations occur are: phytoplankton in highly turbid waters or detecting rare organisms in a dense mixture of other organisms.

\section{OCEANIC PHYTOPLANKTON}

In particular oceanic research has been benefiting from flow cytometry as a tool to analyse the phytoplankton community. Nowadays, FCM is one of the key instruments in oceanic (pico-) phytoplankton research. Cell abundances, taxonomic diversity and fluorescence signatures can be estimated almost in real time with most commercial instruments (Fig. 7). Moreover, most of these instruments turned out to be stable on board ships.

The number of clusters of phytoplankton to be distinguished in the ocean is often limited (usually not exceeding 8). Except for Prochlorococcus and Synechococcus the eukaryotes usually show a continuum rather than distinct clusters (Fig. 7). The resolution of this group can be enhanced using special cluster programs (Bakker Schut et al., 1993) or other statistical methods to examine species diversity without (Li, 1997; Carr et al., 1996) or including neural networks (Balvoort et al., 1992; Boddy et al., 1994). Another way to enhance the resolution of the phytoplankton component is to stain the DNA. Since the c.v.'s of the DNA signals is much lower (10 to 15\%) than that of scatter or autofluorescence signal (c.v. $>50 \%$ ) nearly identical sized cells appear as separated groups in the DNA frequency histograms (Fig. 8). Nevertheless, to assess the species
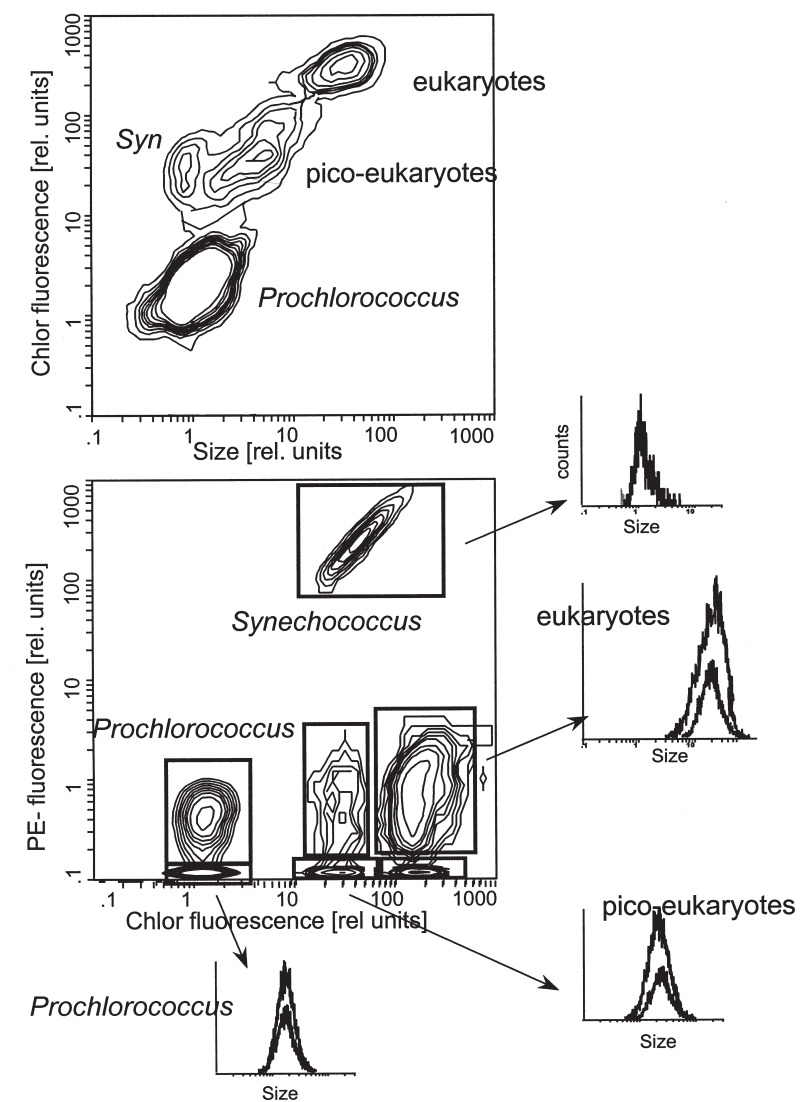

FIG. 7. - Side angle Scattered Signal and autofluorescence signals (chlorophyll, > 650 nm) and phycoerythrin (PE, 530-590 nm) of typical tropical phytoplankton community (North Atlantic, sample taken at $90 \mathrm{~m}$ ). 


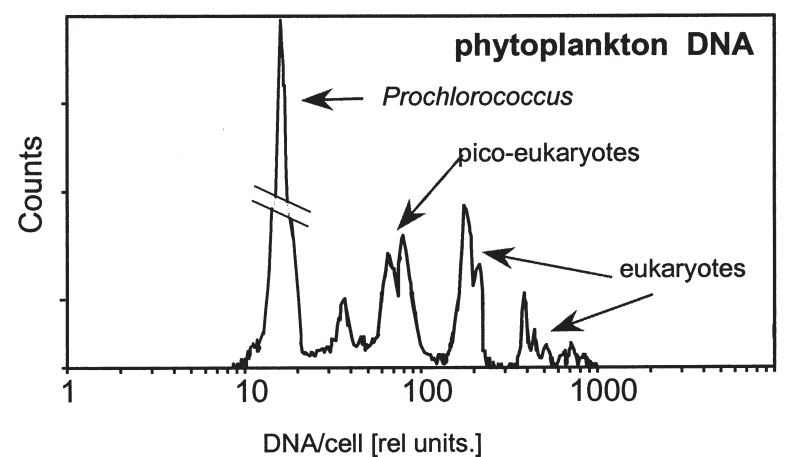

FIG. 8. - Frequency histograms and relative DNA content of oceanic phytoplankton sample showing more details of the diversity in eukaryotic species present (same sample as shown in Fig. 7).

diversity in more detail, FCM measurements need to be complemented with other tools. The combination of cell sorting with (light, TEM, SEM) microscopic observations or immunology and molecular biology (Knauber et al., 1996; Urbach and Chisholm, 1998) should provide a detailed description of the species diversity (see Reckermann, 2000).

\section{PROCHLOROCOCCUS; AN EXAMPLE OF A SUCCESS STORY}

Flow cytometry, next to plant-pigment analysis, played a prominent role in the 'discovery' of the smallest known phytoplankter so far Prochlorococcus marinus (Chisholm et al., 1988; Chisholm et al., 1992). For excellent reviews on this topic we recommend Partensky et al. (1999) and Partensky et al. (in press). This unique prokaryotic phytoplankter possesses a unique pigment spectrum including chlorophyll $-a_{2}$ and occasionally also chlorophyll- $b_{2}$ (Chisholm et al., 1988; Partensky et al., 1993, Veldhuis and Kraay, 1990). Due to its small size (cell size ranges from 0.6 to $0.9 \mu \mathrm{m}$ ) and dim autofluorescence, the high number (up to 300,000 per $\mathrm{ml}$ ) were often mistaken for heterotrophic bacteria (Sieracki et al., 1995). An inventory of its global distribution reveals that this species is the abundant phytoplankter in all major (sub)tropical oceans both in terms of biomass and productivity: North Atlantic (Neveux et al., 1989; Olson et al., 1990; Veldhuis

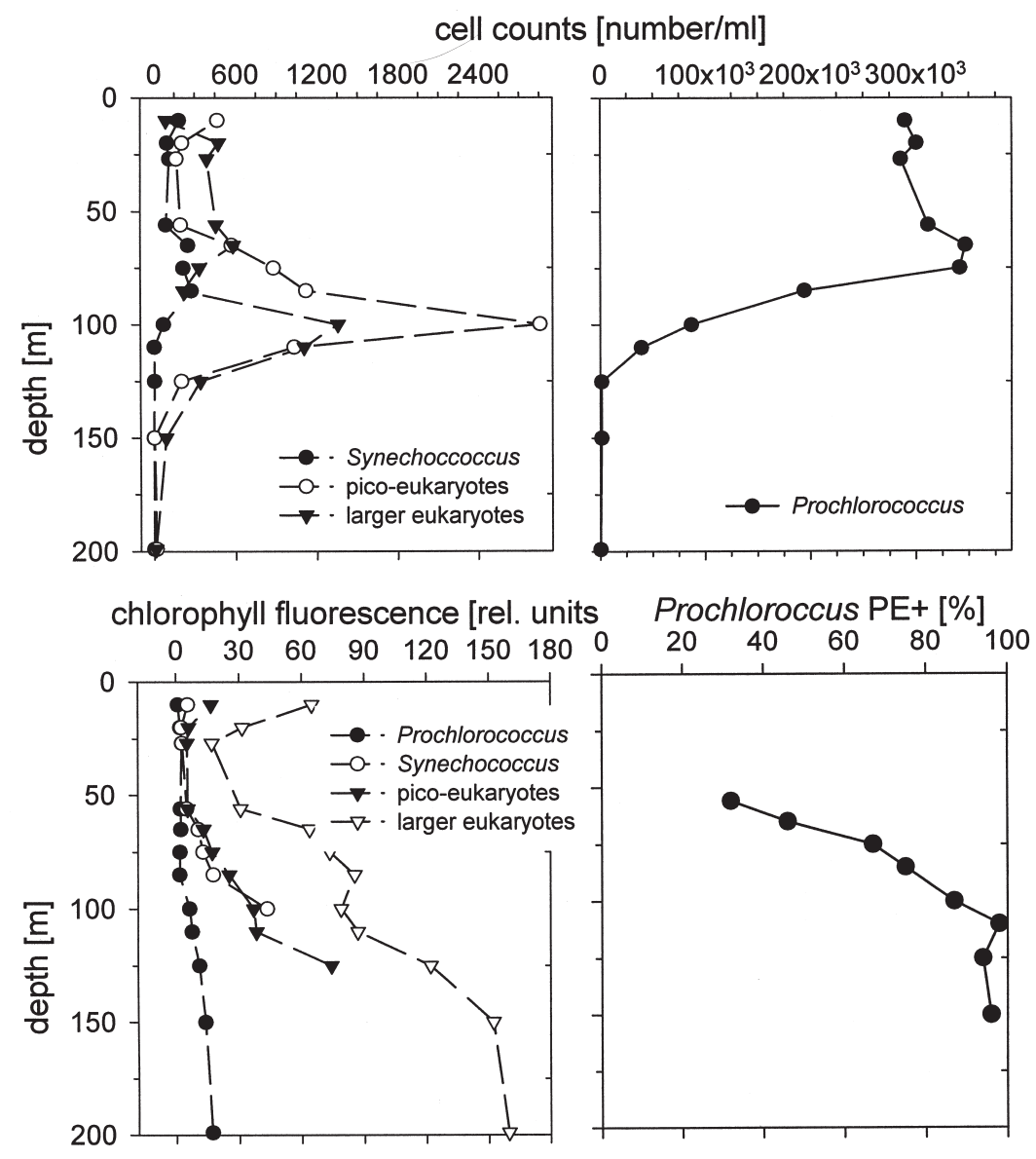

FIG. 9. - Typical vertical profile of phytoplankton abundance, relative cellular fluorescence of different groups identified and \% distribution of PE-containing Prochlorococcus. 
and Kraay, 1990), Pacific (Chavez et al., 1991; Campbell and Vaulot, 1993), Mediterranean (Vaulot et al., 1990; Vaulot and Partensky, 1992), Red Sea and Indian Ocean (Veldhuis and Kraay, 1993; Lindell and Post, 1995). Unlike many other oceanic phytoplankton species Prochlorococcus is present over the entire euphotic zone, often below $0.1 \%$ of surface irradiance (Fig. 9). Although the species adapts to reduced light intensities by increasing its pigment concentration, strain specific pigment compositions have been recorded (Partensky et al., 1993, 1997; Hess et al., 1996). Whereas the genome size (Veldhuis et al., 1997a), of most isolates examined show great consistency, molecular tools reveal the co-occurrence of different strains (Scanlan et al., 1996). Differences in 16S rRNA sequences are only small (Moore et al., 1998) and strains form major clades (Ferris and Palenik, 1998) but their ecophysiological variability is still considerable.

\section{GROWTH RATE}

In ecological studies a proper calculation of the specific growth rates is essential to estimate the role of phytoplankton in the fluxes of energy and matter. Tracing the wax and wane of key phytoplankton species as well as species succession is crucial to the understanding of the functioning of ecosystems. Flow cytometry provides an elegant and accurate method to measure specific cell division rates on the level of individual species. Basically the method is an improvement of the frequency of dividing cells method (Braunwarth and Sommer, 1985; Heller, 1977; Smayda, 1975). The theoretical concepts are well-documented (Chang and Carpenter, 1988; Chang and Carpenter, 1990; Chang and Dam, 1993). Growth rate estimates are based on the DNA frequency distribution traced over a given period of time, usually a $24 \mathrm{~h}$ (light/dark) period (Vaulot et al., 1995; Van Bleijswijk and Veldhuis, 1995; Pan and Cembella., 1998; Fig. 10).

Fortunately, the cell division in most phytoplankton species is accompanied by a bimodal DNA distribution with vegetative cells containing exactly 1 or 2 copies of the genome. Using a simple mathematical model, the DNA distribution in the $\mathrm{G}_{0 / 1}$ and $\mathrm{G}_{2}$ (based on a Gaussian distribution) and an intermediate region, containing cells in the S-phase (Synthesis phase) can be assigned. Next, the cell specific growth rate $\left(\mu_{\mathrm{DNA}}\right)$ is estimated using the fraction of cells in $S$ and $G_{2}$ phase during the time course of the measurements (Fig 10). The major advantage of this approach is that growth rates can
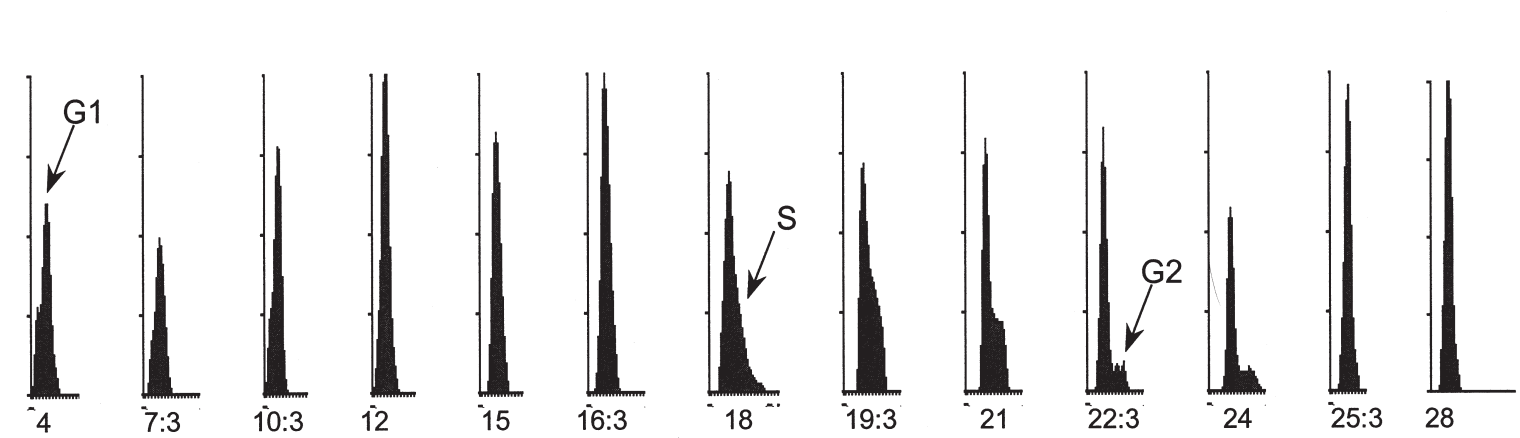

\section{DARK}

LIGHT DARK
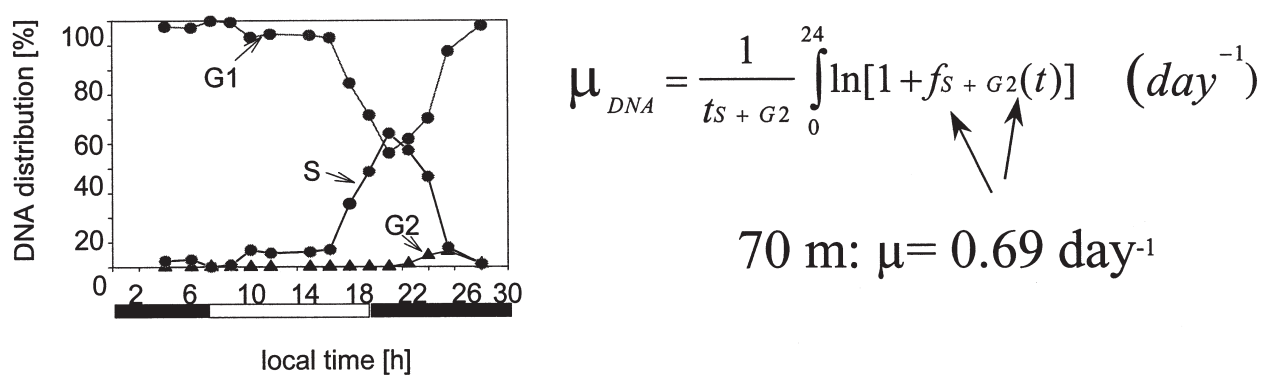

$70 \mathrm{~m}: \mu=0.69$ day $^{-1}$

FIG. 10. - DNA frequency histograms of Prochlorococcus samples taken at different sampling intervals over a 28-hour (light/dark) period. DNA distribution in $\mathrm{G}_{0 / 1}, \mathrm{~S}$ and $\mathrm{G}_{2}$ fraction (insert) and equation used to calculated cell specific growth rate $\left(\mu_{\mathrm{DNA}}\right)$. Sample was taken at $70 \mathrm{~m}$ and calculated growth rate was 0.69 day $^{-1}$. 

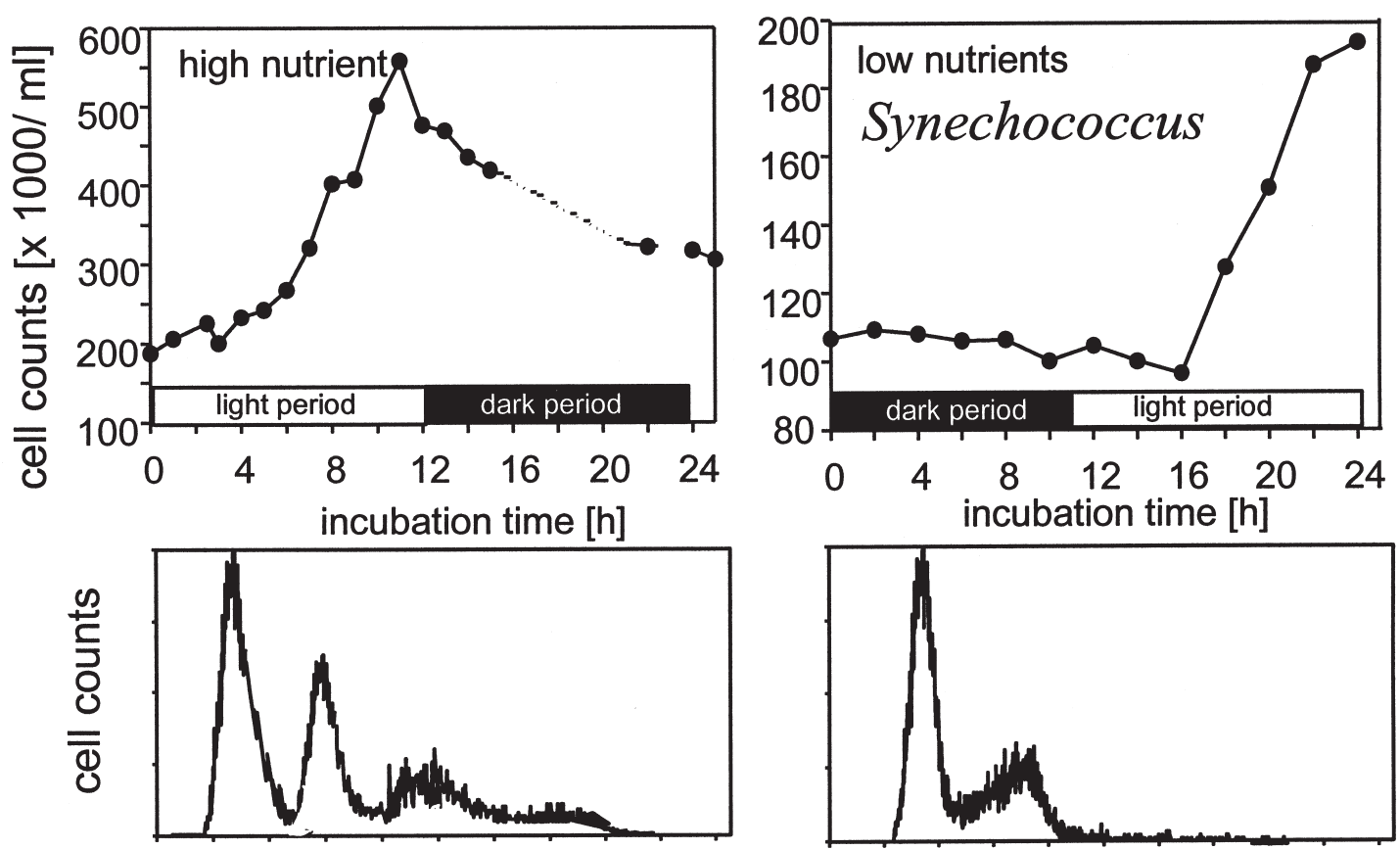

relative DNA content/cell

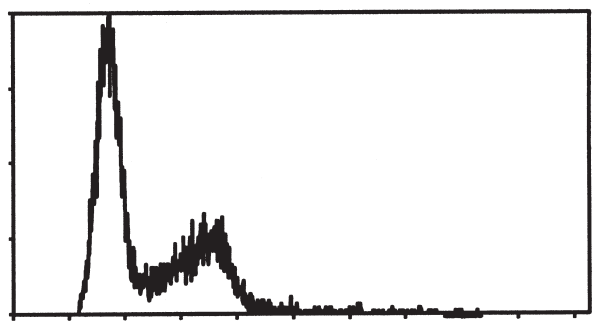

relative DNA content/cell

FIG. 11. - Time course changes in cell abundance of two different populations of Synechococcus in a nutrient replete (left) and nutrient depleted area (right) Sample collected in the Arabian Sea and incubated in $250 \mathrm{ml}$ bottles (upper panel). Typical DNA distribution with an asynchronized type and bimodal type (lower panel). Samples for DNA profiles are taken shortly before the start of the dark period.

be determined at the level of individual species but most of all in situ, omitting any manipulation of the sample.

Recently, the two best studied oceanic phytoplankton genera in this respect, the unicellular Synechococcus spp. and Prochlorococcus spp. showed a deviation of this bimodal concept. Various strains of the coccoid Synechococcus examined show a much more complex cell cycle model matching that of typical prokaryotes (Cooper and Helmstetter or $E$. coli model, Cooper and Helmstetter, 1968). This includes multiple copies of the genome or an asynchrony type with multiple peaks (Armbrust et al., 1989, Binder and Chisholm, 1995, Fig. 11). Also Prochlorococcus deviates from this bimodal concept at the higher growth rates with next to a $G_{2}$ a clear $\mathrm{G}_{4}$ phase (Shalapyonok et al., 1998). This atypical DNA frequency distribution in Synechococcus complicates an accurate estimate of the DNA distribution in the different stages, hence the calculation of the specific growth rate (Binder and Chisholm, 1995). We observed the asynchronous type in the Arabian Sea under nutrient repleted conditions (Fig. 11), whereas the bimodal type occurred in nutrient deprived waters.

Whereas the DNA-cell-cycle model provides a fairly good estimate of the gross growth rate $\left(\mu_{\mathrm{G}}\right)$, field populations of phytoplankton are also subject to grazing by microzooplankton and heterotrophic nanoflagellates. Therefore, in any traceable amount of water, the variability in species abundance on a daily base reflects the net change in population size. Combined with the $\mu_{\mathrm{DNA}}$ the grazing rate can be calculated simultaneously according to:

$$
\mu_{\mathrm{G}}=\mu_{\mathrm{DNA}}=\mu_{\text {cell }}+\mathrm{g}\left(\mathrm{d}^{-1}\right)
$$

Wherein $\mu_{\mathrm{G}}$ is gross growth rate, which is equal to $\mu_{\mathrm{DNA}} ; \mu_{\text {cell }}$ is the overall variation in cell number on a daily base and $g$ is grazing pressure. All parameters can be assessed on the species level or even on level of sub-populations (Reckermann and Veldhuis, 1997).

\section{STAINING AND PROBING APPLICATIONS}

Except for staining DNA, very few other aspects of phytoplankton physiology have been addressed although there are numerous ways flow cytometry can be applied in single cell physiology.

Nowadays a variety of FITC-conjugated lectins are commercially available and they have been examined mainly microscopically. These probes 

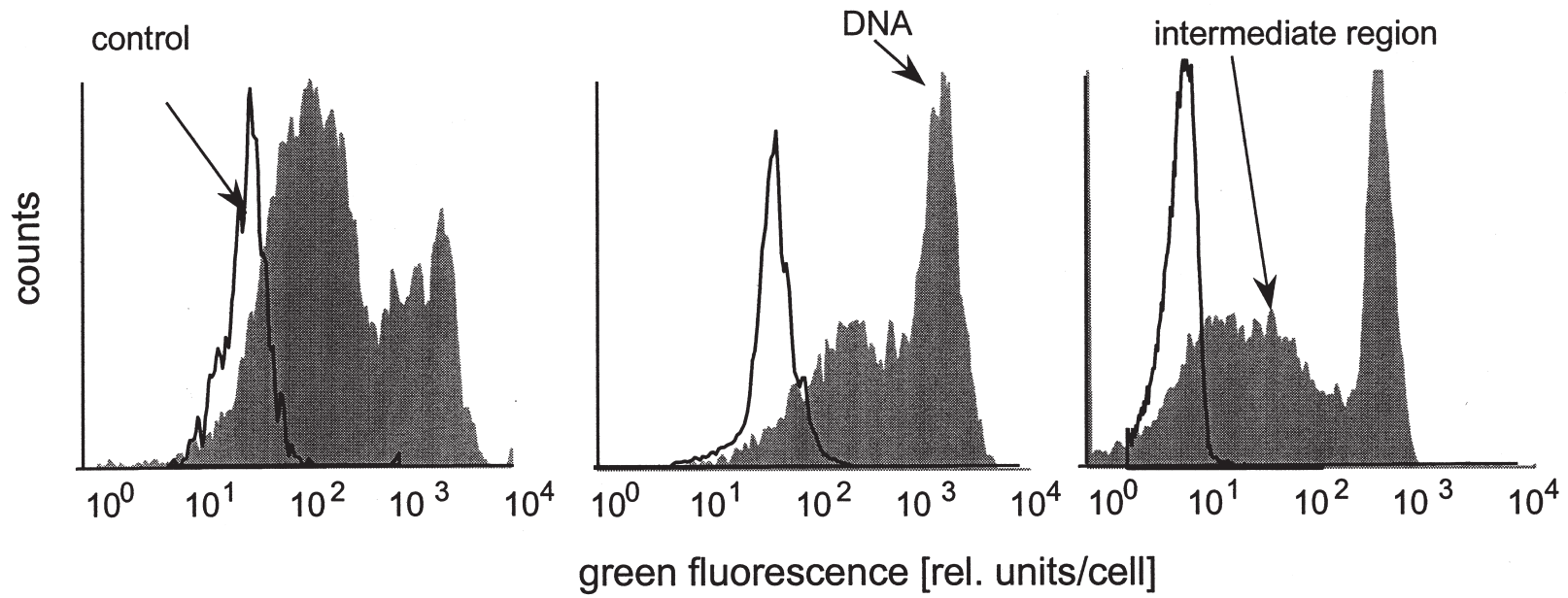

FIG. 12. - Frequency histograms of green fluorescence staining of live phytoplankton samples stained with a DNA specific dye impermeable in live cells. Control: green autofluorescence signal of the cells prior to staining. DNA-signal indicates DNA signal typically found in fixed samples (maximum possible staining). Data of three eukaryotic phytoplankton groups. (North Atlantic in spring 1998). (Veldhuis et al., in press).

were mainly used to study class and cell structure specific binding (Sengbusch et al., 1982; Sengbusch and Müller, 1983; Costas and Rodas, 1994; Costas et al., 1995). Alternative stains to detect specific cellular compounds are Calcofluor White-ST, which stains typically cellulose and chitin fibres, the lipid stains Neutral Red (Crippen, 1974) and Nile Red (Cooksey et al., 1987; Macho et al., 1996). None of these dyes have found a wide application so far in aquatic flow cytometry (see Jochem, 2000).

Next to measuring structural or bio-chemical components FCM can also be applied to address the physiological condition of the phytoplankton cells (Jochem, loc. cit.). In this context phytoplankton viability/automortality is a research topic currently receiving considerable attention. The loss in vitality is nowadays, next to grazing and sedimentation, considered to be the third main factor reducing the size of the population in the field. Cell lysis has been found in particular under poor environmental conditions (Van Bleijswijk et al., 1994; Brussaard et al., 1995; Agustí et al., 1998). It is highly likely, but so far not proven, that this cell death could be based on a programmed process like in multicellular organisms (Brusch et al., 1990). Both light and nitrogen stress have been assigned to induce changes in the protein composition and enhanced activity of proteases in phytoplankton (Berges and Falkowski, 1998). So far, this automortality process has been examined using large sample values. Recently, we have examined an alternative method to test the viability of phytoplankton on the level of the individual cell using FCM. Essentially, the method is based on the membrane integrity of the cells (Veldhuis et $a l$. , in press). Like the dye PI, which is used to assess cell death or often better known as apoptosis in the medical field, we used a green fluorescent DNA-specific dye (SYTOX Green) also impermeable in live cells (Fig. 12). It turns out that healthy intact cells remain unstained and dead cells show a full staining of the cellular DNA content corresponding to the signal found in preserved samples. In freshly (unfixed samples) often a third, intermediate population, was observed of cells with a partly comprised cell membrane. Since the disintegration of the membrane structure is typical of a late stage of cell mortality it is clear that cells which are only partly stained have just entered the final stage of automortality. The presence of a demographic structure in a population may well explain e.g. the high degree of variability in UV-B sensitivity as previously observed in the diatom Cyclotella sp. (Buma et al., 1995).

Applying the viability assay using freshly collected water samples of the North Atlantic Ocean in spring showed a great variability in staining among the different algal populations present. The percentage of positively stained cells (indicative of comprised membrane permeability) varied from $5 \%$ in Synechococcus to $40 \%$ in other small eukaryotes (Fig. 13). For a spring situation this percentage is relatively high since it indicates the existence of a relatively high proportion of cells with a reduced vitality. To what extent this influences species succession and the cycling of organic matter in the ocean remains a future challenge. 

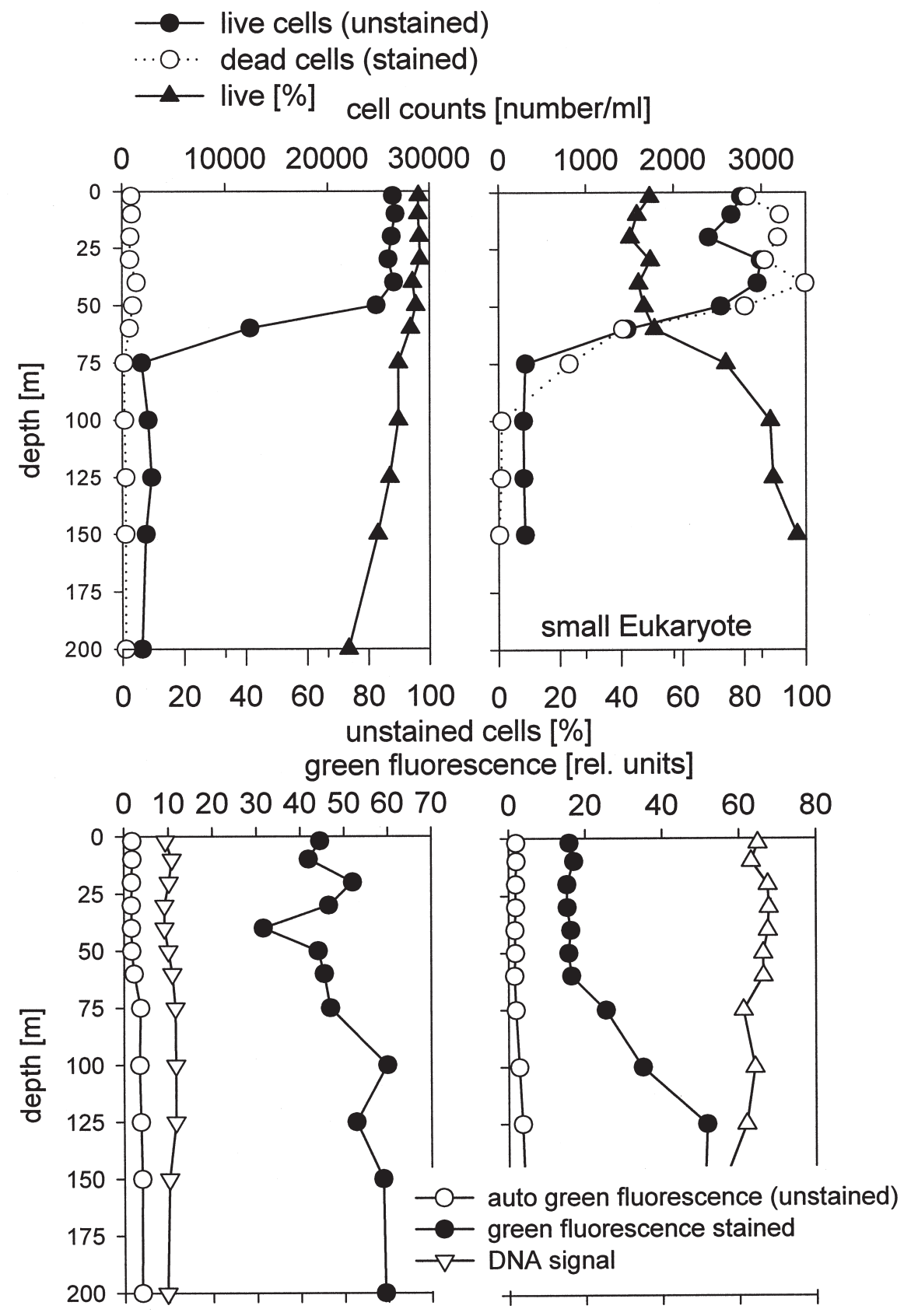

FIG. 13. - Vertical distribution of live and dead cells of Synechococcus and a picoeukaryote (North Atlantic in spring 1998, upper panel). Relative green fluorescence of the different live and dead fraction of the population and typical DNA signal in fixed samples (lower panel).

\section{ACKNOWLEDGEMENTS}

The authors wish to thank Judith van Bleijswijk, Anita Buma, Terry Cucci and Marcus Reckermann for their contribution. Mr. M. Cheetman and Mrs W. Harkema of Beckman Coulter NL are acknowledged for their continuous support in improving the flow cytometry facility at NIOZ. Gerhard Cadée is acknowledged for his stimulating remarks. This is NIOZ publication no. 3475.

\section{REFERENCES}

Agustí, S., M.P. Satta, M.P. Mura and E. Benavent. - 1998. Dissolved esterase activity as a tracer of phytoplankton lysis: Evidence of high phytoplankton lysis rates in the northwestern Mediterranean. Limnol. Oceanogr., 43: 1836-1849.

Armbrust, E.V., J.D. Bowen, R.J. Olson and S.W. Chisholm. 1989. Effect of light on the cell cycle of a marine Synechococcus_strain. Appl. Environm. Microbiol., 55: 425-432.

Bakker Schut, T.C., B.C.D. Grooth and J. Greve. - 1993. Cluster analysis of flow cytometric list mode data on personal computer. Cytometry, 14: 649-659.

Balvoort, H.W., J. Snoek, J.R.M. Smits, L.W. Breedfeld, J.W. Hofstraat and J. Ringelberg. - 1992. Automatic identification of 
algae: neural network analysis of flow cytometric data. $J$. Plankton Res., 14: 575-589.

Berges, J.A. and P.G. Falkowski. - 1998. Physiological stress and cell death in marine phytoplankton: Induction of proteases in response to nitrogen and light limitation. Limnol. Oceanogr., 43: 129-135.

Binder, B.J. and S.W. Chisholm. - 1995. Cell cycle regulation in marine Synechococcus sp. strains. Appl. Environ. Microbiol., 61: 708-717.

Boddy, L., C.W. Morris, G.A. Tarran and P.H. Burkill. - 1994. Neural network analysis of flow cytometric data for 40 marine phytoplankton species. Cytometry, 18: 283-293.

Braunwarth, C. and U. Sommer. - 1985. Analyses of the in situ growth rates of cryptophyceae by use of the mitotic index technique. Limnol. Oceanogr., 30: 893-897.

Brusch, W., L. Kleine and M. Tenniswood. - 1990. The biochemistry of cell death by apoptosis. Biochem. Cell. Biol., 88: 10711074.

Brussaard, C.P.D., R. Riegman, A.A.M. Noordeloos, G.C. Cadee, H. Witte, A.J. Kop, G. Nieuwland, F.C.v. Duyl and R.P.M. Bak. - 1995. Effects of grazing, sedimentation and phytoplankton cell lysis on the structure of a coastal pelagic food web. Mar. Ecol. Prog. Ser., 123: 259-271.

Buma, A.G.J., E.J. vanHannen, L. Roza, M.J.W. Veldhuis and W.W.C. Giekses. - 1995. Monitoring ultraviolet-B-induced DNA damage in individual diatom cells by immunofluorescent thymine dimer detections. J. Phycol., 31: 314-321.

Burkill, P.H.. - 1987. Analytical flow cytometry and its application to marine microbial ecology. IN: M.A. Sleigh (Edt), pp. 139166, J.Wiley \& Sns., Chichester, W. Sussex (England).

Burkill, P.H. and R.F.C. Mantoura. - 1990. The rapid analysis of single marine cells by flow cytometry. Phil. Trans. R. Soc. Lond., 333: 99-112.

Campbell, L., H.A. Nolla and D. Vaulot. - 1994. The importance of Prochlorococcus to community structure in the central North Pacific Ocean. Limnol. Oceanogr., 39: 954-961.

Campbell, L. and D. Vaulot. - 1993. Photosynthetic picoplankton community structure in the subtropical north Pacific Ocean near Hawaii (station ALOHA). Deep-Sea Res., 40: 2043-2060.

Carr, M.R., G.A. Tarran and P.H. Burkill - 1996. Discrimination of marine phytoplankton species through the statistical analysis of their flow cytometric signatures. J. Plankton Res., 18: 12251238.

Chang, J. and E.J. Carpenter. - 1988. Species-specific phytoplankton growth rates via diel DNA synthesis cycles. II: DNA quantification and model verification in the dinoflagellate Heterocapsa triquetra. Mar. Ecol. Prog. Ser., 44: 287-296.

Chang, J. and E.J. Carpenter. - 1990. Species-specific phytoplankton growth rates via diel DNA synthesis cycles. IV: Evaluation of the magnitude of error with computer-simulated cell populations. Mar. Ecol. Prog. Ser., 65: 293-304.

Chang, J. and H.G. Dam. - 1993. The influence of grazing on the estimation of phytoplankton growth rate via cell cycle analysis: modeling and experimental evidence. Limnol. Oceanogr., 38: 202-212.

Charpy, L. and J. Blanchot. - 1998. Photosynthetic picoplankton in French Polynesian atoll lagoons: esitmation of taxa contribution to biomass and production by flow cytometry. Mar. Ecol. Prog. Ser., 162: 57-70.

Chavez, F.P., K.R. Buck, K. Coale, J.H. Martin, G.R. DiTullio, N.A. Welschmeyer, A.C. Jacobson and R.T. Barber. - 1991. Growth rates, grazing, sinking and iron limitation of equatorial Pacific phytoplankton. Limnol. Oceanogr., 36: 1816-1833.

Chisholm, S.W.. - 1992. Phytoplankton size. In: P.G. Falkowski and A.D. Woodhead (eds): Primary Production and Biogeochemical Cycles in the Sea, pp. 213-237. Plenum Press, N-Y.

Chisholm, S.W., S.I. Frankel, R. Goericke, R.J. Olson, B. Palenik, J.B. Waterbury, L. West-Johnsrud and E.R. Zettler. - 1992. Prochlorococcus marinus nov. gen. nov. sp.: an oxyphototrophic marine prokaryote containing divinyl chlorophyll a and b. Arch. Microbiol., 157: 297-300.

Chisholm, S.W., R.J. Olson, E.R. Zettler, R. Goericke, J.B. Waterbury and N.A. Welschmeyer. - 1988. A novel free-living prochlorophyte abundant in the oceanic euphotic zone. Nature., 334: 340-343.

Cooksey, K.E., J.B. Guckert, S.A. Williams and P.R. Callis. - 1987. Fluorometric determination of the neutral lipid content of microalgal cells using Nile Red. J. Microbiol., 6: 333-345.
Cooper, S. and C.E. Helmstetter. - 1968. Chromosome replication and the division cycle of Escherichia coli B/r. J. Mol. Bio., 31: 519-540.

Costas, E. and V.L. Rodas. - 1994. Identification of marine dinoflagellates using fluorescent lectins. J. Phycol., 30: 987-990.

Costas, E., R. Zardoya, J. Bautista, A. Garrido, C. Rojo and V. Lopez-Rodas. - 1995. Morphospecies vs. genospecies in toxic marine dinoflagellates: an analysis of Gymnodinium catenatum/Gyrodinium impudicum and Alexandrium minutum/A. lusitanicum using antibodies, lectins, and gene sequences. $J$. Phycol., 31: 801-807.

Crippen, R.W., \& J.J. Perrier. - 1974. The use of neutral red and evans blue for live-dead determinations of marine plankton. Stain Techn., 40: 97-104.

Dubelaar, G.B.J.and P.L. Gerritzen. - 2000. CytoBuoy: A step forward towards using flow cytometry in operational oceanography. Sci.Mar., 64(2): 255-265.

Dubelaar, G.B.J., P.L. Gerritzen, A.E.R. Beeker, R.R. Jonker and K. Tangen. - 1999. Design and first results of CytoBuoy: A wireless flow cytometer for in situ analysis of marine and fresh waters. Cytometry, 37: 247- 254.

Dubelaar, G.B.J., A.C. Groenewegen, W. Stokdijk, G.J.v.d. Engh and J.W.M. Visser. - 1989. Optical plankton analyser: a flow cytometer for plankton analysis, II: Specifications. Cytometry, 10: $529-539$.

Ferris, M.J. and B. Palenik. - 1998. Niche adaptation in ocean cyanobacteria. Nature., 396: 226-228.

Heller, M.D. - 1977. The phased division of the freshwater dinoflagellate Ceratium hirundinella and its use as a method of assessing growth in natural populations. Freshwater Biol., 7: 527-533.

Hess, W.R., F. Partensky, G.W.M. vanderStaay, J.M. Garcia-Fernandez, T. Börner and D. Vaulot. - 1996. Coexistence of phycoerythrin and a chlorophyll $\mathrm{a} / \mathrm{b}$ antenna in a marine prokaryote. Proceeding of the National Academy of Sciences USA., 93: 11126-11130.

Hofstraat, J.W., M.E.J. de Vreeze, W.J.M. van Zeijll, L. Peperzak, J.C.H. Peeters and H.W. Balvoort. - 1991. Flow cytometric discrimination of phytoplankton size classes by fluorescence emission and excitation properties. J. Fluoresc., 1: $249-265$

Holm-Hansen, O.. - 1969. Algae: amounts of DNA and organic carbon in single cells. Science (Wash. D.C.)., 163: 87-88.

Jeffrey, S.W., R.F.C. Mantoura and S.W. Wright (eds.) -1997. Phytoplankton pigments in oceanography. UNESCO, Paris.

Jochem, F.C. - 2000. Probing the physiological state of phytoplankton at the single-cell level. Sci. Mar., 64(2): 183-195.

Kachel, V. and J. Weitzorrek. - 2000. Flow Cytometry and Integrated Imaging. Sci. Mar., 64(2): 247-254.

Knauber, D.C., E.S. Berry and M.W. Fawley. - 1996. Ribosomal RNA-based oligonucleotide probes to identify marine green ultraplankton. J. Euk. Microbiol., 43: 89-94.

Koike, I., S. Hara, K. Terauchi and K. Kogure. - 1990. Role of submicrometer particles in the ocean. Nature., 345: 242-244.

Leary, J.F. - 1994. Strategies for rare cell detection and isolation. In: Z. Darzynkiewicz, J.P. Robinson \& H.A. Crissman (Eds), Methods in cell biology., 42 Part B: Flow cytometry: 331-369.

Li, W.K.W. - 1990. Particles in "particle-free" seawater: growth of ultraphytoplankton and implications for dilution experiments. Can. J. Fish. Aquat. Sci., 47: 1258-1268.

Li, W.K.W. -1995. Composition of ultraphytoplankton in the central North Atlantic. Mar. Ecol. Prog. Ser., 122: 1-8.

Li, W.K.W. - 1997. Cytometric diversity in marine ultraphytoplankton. Limnol. Oceanogr., 42: 874-880.

Li, W.K.W., T. Zohary, Y.Z. Yacobi and M. Wood. - 1993. Ultraphytoplankton in the eastern Mediterranean Sea: towards deriving phytoplankton biomass from cytometric measurements of abundance, fluorescence and light scatter. Mar. Ecol. Prog. Ser., 102: 79-87.

Lindell, D. and A.F. Post. - 1995. Ultraphytoplankton succession is triggered by deep winter mixing in the Gulf of Elat (Aqaba), Red Sea. Limnol. Oceanogr., 40: 1130-1141.

Macho, A., Z. Mishal and J. Uriel. - 1996. Molar quantification by flow cytometry of fatty acid binding to cells using dipyrrometheneboron difluoride derivates. Cytometry, 23: 166-173.

Medlin, L., G.L.A. Barker, L. Campbell, J.C. Green, P.K. Hayes, D. Marie, S. Wreiden and D. Vaulot. - 1996. Genetic characterisation of Emiliania huxleyi. J. Mar. Syst., 9: 13-31. 
Moore, L.R., G. Rocap and S.W. Chisholm. - 1998. Physiology and molecular phylogeny of coexisting Prochlorococcus ecotypes. Nature, 393: 464-467.

Morel, A. - 1991. Optics of marine particles and marine optics. In: S. Demers (ed.): Particle analysis in oceanography. NATO ASI Series, Series G: Ecological Sciences, Vol. 27, pp. 141188. Springer, Berlin.

Neveux, J., D. Vaulot, C. Courties and E. Fukai. - 1989. Green photosynthetic bacteria associated with the deep chlorophyll maximum of the Sargasso Sea. Compt. Rend. l'Acad. Sci. Paris., 308: 9-14.

Olson, R.J., S.W. Chisholm, E.R. Zettler, M.A. Altabet and J.A. Dusenberry. - 1990. Spatial and temporal distributions of prochlorophyte picoplankton in the north Alantic Ocean. DeepSea Res., 37: 1033-1051.

Olson, R.J., S.W. Chisholm, E.R. Zettler and E.V. Armbrust. 1988. Analysis of Synechococcus pigment types in the sea using single and dual beam flow cytometry. Deep-Sea Res., 35: 425-440.

Olson, R.J., E.R. Zettler and K.O. Anderson. - 1989. Discrimination of eukaryotic phytoplankton cell types from light scatter and autofluorescence properties measured by flow cytometry. Cytometry, 10: 636-643.

Olson, R.J., E.R. Zettler, S.W. Chisholm and J.A. Dusenberry. 1991. Advances in oceanography through flow cytometry. In: S. Demers (ed.): Particle analysis in oceanography. NATO ASI Series, Series G: Ecological Sciences, Vol. 27, pp. 351399. Springer, Berlin.

Paau, A.S., J. Oro and J.R. Cowles. - 1978. Application of microfluorometry to the study of algal cells and isolated chloroplasts. J. Exp. Botany. 29: 1011-1020.

Pan, Y. and A.D. Cembella. - 1998. Flow cytometric determination of cell cycles and growth rates of Prorocentrum spp. In: $B$. Reguera, J. Blanco, M.L. Fernadez, and T. Wyatt, (eds), Harmful Algae. Xunta de Galicia and Intergovernmental Oceanographic Commission of UNESCO, pp.173-176.

Partensky, N.H. F., W.K.W. Li, O. Ulloa and D. Vaulot. - 1993. Photoacclimation of Prochlorococcus sp. (prochlorophyta) strains isolated from the North Atlantic and the Mediterranean Sea. Plant Physiol, 101: 285-296.

Partensky, F., J. Blanchot and D. Vaulot - in press. Differential distribution of Prochlorococcus and Synechococcus in oceanic waters: a review. In: Charpy, L., Larkum H. (Eds.): Marine cyanobacteria and related organisms. Institute Oceanographique, Monaco.

Partensky, F., W.R. Hess and D. Vaulot. - 1999. Prochlorococcus, a marine photosynthetic prokaryote of global significance. Microbiol. Mol. Biol. Rev., 63: 106-127.

Partensky, F., J. LaRoche, K. Wyman and P.G. Falkowski. - 1997. The divinyl-chlorophyll a-b-protein complexes of two strains of the oxyphototrophic marine prokaryote Prochlorococcus: Characterisation and response to changes in growth irradiance. Photosynthesis Res., 51: 209-222.

Peeters, J.C.H., G.B.J. Dubelaar, J. Ringelberg and J.W.M. Visser. - 1989. Optical plankton analyser: a flow cytometer for plankton analysis, I: Design Consideration. Cytometry, 10: 522-528.

Peperzak, L., E.G. Vrieling, B. Sandee and T. Rutten. - 2000 Immuno flow cytometry in marine phytoplankton research. $S c i$. Mar., 64(2): 165-181.

Phinney, D.A. and T.L. Cucci. - 1989. Flow cytometry and phytoplankton. Cytometry, 10: 511-521.

Reckermann, M. - 2000. Flow Sorting in Aquatic Ecology. Mar. Sci., 64(2): 235-246

Reckermann, M. and M.J.W. Veldhuis. - 1997. Trophic interactions between picophytoplankton and micro- and nanozooplankton in the western Arabian Sea during the NE monsoon 1993. Aquat. Microb. Ecol., 12: 263-273.

Sakshaug, E., S. Demers and C.M. Yentsch. - 1987. Thalassiosira oceanica and T. pseudonana: two different photoadaptational responses. Mar. Ecol. Prog. Ser., 41: 275-282.

Scanlan, D.J., W.R. Hess, F. Partensky, J. Newman and D. Vaulot. - 1996. High degree of genetic variation in Prochlorococcus (Prochlorophyta) revealed by RFPL analysis. Eur. J. Phycol., 31: $1-9$.

Sengbusch, P. . M. Mix, I. Wachholz and E Manshard - 1982 FITC-labeled lectins and calcufluor white ST as probes for the investigation of the molecular architecture of cell surfaces. Studies on conjugatophycean species. Protoplasma, 111: 38-52.
Sengbusch, P.v. and U. Müller. - 1983. Distribution of glycoconjugates at algal cell surfaces as monitored by FITC-conjugated lectins. Protoplasma, 114: 103-113.

Shalapyonok, A., R.J. Olson and L.S. Shalapyonok. - 1998. Ultradian growth in Prochlorococcus spp. Appl. Environm. Microbiol., 64: 1066-1069.

Shimada, A., T. Hasegawa, I. Umeda, N. Kadoya and T. Maruyama. - 1993. Spatial mesoscale patterns of West Pacific picophytoplankton as analysed by flow cytometry: their contribution to subsurface chlorophyll maxima. Mar. Biol., 115: 209215.

Sieracki, C.K., M.E. Sieracki and C.S. Yentsch. - 1998. An imaging-in-flow system for automated analysis of marine microplankton. Mar. Ecol. Prog. Ser., 168: 285-296.

Sieracki, M.E., E.M. Haugen and T.L. Cucci. - 1995. Overestimation of heterotrophic bacteria in the Sargasso Sea: direct evidence by flow and imaging cytometry. Deep-Sea Res., 42: 1399-1409.

Smayda, T.J.. - 1975. Phased cell division in natural populations of the marine diatom Ditylum brigthwellii and the potential significance of diel phytoplankton behavior in the sea. Deep-Sea Res. I. $22: 151-165$.

Sosik, H.M., S.W. Chisholm and R.J. Olsen. - 1989. Chlorophyll fluorescence from single cells: interpretation of flow cytometric signals. Limnol. Oceanogr., 34: 1749-1761.

Strathmann, R.R. - 1967. Estimating the organic carbon content of phytoplankton from cell volume or plasma volume. Limnol. Oceanogr., 12 411-418:

Urbach, E. and S.W. Chisholm. - 1998. Genetic diveristy in Prochlorococcus populations flow cytometrically sorted from the Sargasso Sea and Gulf stream. Limnol. Oceanogr., 43: 1615-130.

Van Bleijswijk, J.D.L., R.S. Kempers, P.v.d. Wal, P. Westbroek, J.K. Egge and T. Lukk. - 1994. Standing stocks of PIC, POC, PON and Emiliania huxleyi coccospheres and liths in sea water enclosures with different phoshate loadings. Sarsia, 79: 307-317.

Van Bleijswijk, J.D.L. and M.J.W. Veldhuis. - 1995. In situ gross growth rates of Emiliania huxleyi in enclosures with different phosphate loadings revealed by diel changes in DNA content. Mar. Ecol. Prog. Ser., 121: 271-277.

Vaulot, D., J.-L. Birrien, D. Marie, R. Casotti, M.J.W. Veldhuis, G.W. Kraay and M.-J. Chretiennot-Dinet. - 1994. Morphology, ploidy, pigment composition, and genome size of cultured strains of Phaeocystis (Prymnesiophyceae). J. Phycol., 30: 1022-1035.

Vaulot, D., D. Marie, R.J. Olson and S.W. Chisholm. - 1995. Growth of Prochlorococcus, a photosynthetic prokaryote, in the Equatorial Pacific Ocean. Science, 268: 1480-1482.

Vaulot, D. and F. Partensky. - 1992. Cell cycle distributions of prochlorophytes in the north western Mediterranean Sea. DeepSea Res., 39: 727-742.

Vaulot, D., F. Partensky, J. Neveux, R.F.C. Mantoura and C.A. Llewellyn. - 1990. Winter presence of prochlorophytes in surface waters of the northwestern Mediterranean Sea. Limnol. Oceanogr., 35: 1156-1164.

Veldhuis, M.J.W., T.L. Cucci and M.E. Sieracki. - 1997a. Cellular DNA content of marine phytoplankton using two new fluorochromes: taxonomic and ecological implications. J. Phycol., 33: 527-541.

Veldhuis, M.J.W. and G.W. Kraay. - 1990. Vertical distribution and pigment composition of a picoplanktonic prochlorophyte in the subtropical north Atlantic: a combined study of HPLCanalysis of pigments and flow cytometry. Mar. Ecol. Prog. Ser., 68: 121-127.

Veldhuis, M.J.W. and G.W. Kraay. - 1993. Cell abundance and fluorescence of picophytoplankton in relation to growth irradiance and nitrogen availability in the Red Sea. Neth. J. Sea Res., 21: $135-145$.

Veldhuis, M.J.W., G.W. Kraay and K.R. Timmermans. - in press. Assessing viability in phytoplankton: changes in the membrane integrity and effects on photosynthetic activity and growth. Eur. J. Phycol.

Veldhuis, M.J.W., G.W. Kraay, J.D.L. VanBleijswijk and M.A. Baars. - 1997b. Seasonal and spatial variability in phytoplankton biomass, productivity and growth in the north-western Indian Ocean: the southwest and northeast monsoon, 1992-1993. Deep-Sea Res. I., 44: 425-449. 
Verity, P., C.Y. Robertson, C.R. Tronzo, J.R. Nelson and M.E. Sieracki. - 1992. Relationships between cell volume and the carbon and nitrogen content of marine photosynthetic nanoplankton. Limnol. Oceanogr., 37: 1434-1446.

Wood, A.M., P.K. Horan, K. Muirhead, D.A. Phinney, C.M. Yentsch and J.B. Waterbury. - 1985. Discrimination between types of pigments in marine Synechococcus spp. by scanning spectroscopy, epifluorescence microscopy, and flow cytometry. Limnol. Oceanogr., 30: 1303-1315.

Yentsch, C.M., P.K. Horan, K.M. Muirhead, Q. Dortch, E. Haugen, L. Legendre, L.S. Murphy, M.J. Perry, D.A. Phinney, S.A.
Pomponi, R.W. Spinrad, M. Wood, C.S. Yentsch and B.J. Zahuranec. - 1983. Flow cytometry and cell sorting: a technique for analysis and sorting of aquatic particles. Limnol. Oceanogr., 28: 1275-1280.

Yentsch, C.M. and S.A. Pomponi. - 1986. Automated individual cell analysis in aquatic research. Int. Rev. Cytol., 105: 183-243. Yentsch, C.S. and C.M. Yentsch. - 1979. Fluorescence spectral signatures: the characterization of phytoplankton populations by the use of excitation and emission spectra. J. Mar. Res., 37: 471-483. 